\title{
FEKUNDITAS, DIAMETER TELUR, DAN MAKANAN IKAN BUJUK (Channa lucius Cuvier) PADA HABITAT PERAIRAN BERBEDA
}

\author{
Azrita"), Hafrijal Syandri" ${ }^{* *}$, Estu Nugroho ${ }^{* * *}$, Dahelmi" ${ }^{* * * *}$, dan Syaifullah ${ }^{* * * *}$ \\ *) Program Studi Pendidikan Biologi, FKIP, Universitas Bung Hatta \\ Jl. Sumatera Ulak Karang, Padang, Sumatera Barat 25133 \\ E-mail: azrita31@yahoo.com \\ **) Program Studi Budidaya Perairan, Fakultas Perikanan, Universitas Bung Hatta \\ Jl. Sumatera Ulak Karang, Padang, Sumatera Barat 25133 \\ ***) Pusat Penelitian dan Pengembangan Perikanan Budidaya \\ Jl. Ragunan 20, Pasar Minggu, Jakarta Selatan 12540 \\ ${ }^{* * * * *}$ Program Studi Biologi MIPA, Universitas Andalas \\ Kampus Limau Manis, Padang, Sumatera Barat 25163
}

(Naskah diterima: 16 Februari 2012; Disetujui publikasi: 2 Agustus 2012)

\begin{abstract}
ABSTRAK
Fekunditas, diameter telur, dan kebiasaan makanan ikan merupakan bagian dari aspek reproduksi ikan yang sangat penting diketahui. Informasi ini dapat digunakan untuk memprediksi rekruitmen dan pemulihan stok ikan bujuk dalam rangka domestikasi dan budidaya. Penelitian dilakukan dari bulan Januari-November 2010 pada habitat berbeda yaitu di Danau Singkarak-Sumatera Barat, perairan rawa banjiran Pematang Lindung Kabupaten Tanjung Jabung Timur-Jambi, dan perairan Mentulik Kabupaten KamparRiau. Jumlah sampel yang diamati 30 gonad ikan betina TKG III dan IV masing-masing lokasi penelitian. Fekunditas total ikan bujuk dari Danau Singkarak $1.996 \pm 568$ butir

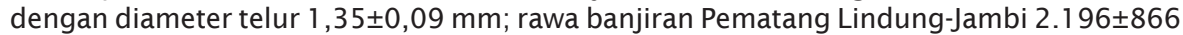
butir dengan diameter telur 1,53 $\pm 0,11 \mathrm{~mm}$; dan rawa banjiran Mentulik Kampar-Riau

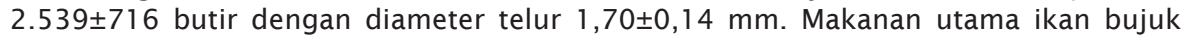
adalah ikan (70,78\%-89,01\%) dan makanan pelengkap udang (5,81\%-16,13\%), katak (1,77\%-4,25\%), dan makanan tambahan serangga air (3,98\%-9,80\%). Berdasarkan jenis makanan tersebut, maka ikan bujuk termasuk kelompok ikan karnivora murni yang bersifat predator.
\end{abstract}

KATA KUNCl: ikan bujuk, fekunditas, diameter telur, kebiasaan makanan

ABSTRACT: Fecundity, egg diameter, and food bujuk fish (Channa lucius Cuvier) in different water habitats. By: Azrita, Hafrijal Syandri, Estu Nugroho, Dahelmi, and Syaifullah

Fecundity, egg diameter, and food habits were part of aspects of the fish reproduction that is very important to know. This information can be used to predict recruitment and fish stock enchancement of bujuk fish within the of domestication and aquaculture. The research was held in Januari until November 2010 in Singkarak Lake, West Sumatra Province, in foodplain Pematang Lindung Sub-district Mendahara Ulu Regency East Tanjung Jabung, Jambi Province, and in foodplain Mentulik Regency Kampar Kiri Hilir, Riau Province. The amount of samples that was observed was 30 gonado of female fish Gonado Maturity Level III and IV in each research location. The total of bujuk fish fecundity from West Sumatra is 1,996 \pm 568 eggs in which each egg has 1.35 \pm 0.09

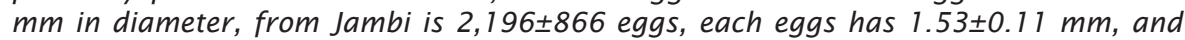


Riau is 2,539 \pm 716 eggs, each has $1.70 \pm 0.14 \mathrm{~mm}$ in diameter. The main food of bujuk fish is fish (70.78\%-89.01\%) and the supplement food are shrimp (5.81\%-16.13\%), frogs (1.77\%-4.25\%), and another additional is water insects (3.98\%-9.80\%). Based on those kinds of food, then bujuk fish is considered as the member of pure carnivore fish which has predatore behavior.

\section{KEYWORDS: bujuk fish, fecundity, egg diameter, food habits}

\section{PENDAHULUAN}

Di perairan umum daratan Indonesia terdapat lima jenis ikan marga Channa yaitu ikan bujuk (Channa lucius Cuvier), ikan gabus (Channa striata Bloch), ikan toman (Channa micropeltes Cuvier), ikan jalai (Channa maruliodes Bleeker), dan ikan serandang (Channa pleurothalmus Bleeker) (Said, 2007). Jenis ikan ini lebih populer dengan sebutan ikan berkepala seperti kepala ular (snakehead) dan nama lokal ikan ini di Riau dan Jambi adalah bujuk (Alawi et al., 2008; Samuel et al., 2002), di Danau Singkarak disebut kiung (Azrita, 2011 ). Ikan ini termasuk black fish yaitu hidup di sungai, rawa banjiran, dan danau di Sumatera (Utomo et al., 2001). Ikan bujuk sudah jarang ditemukan karena penangkapan yang berlebihan dan tidak selektif terhadap ukuran populasi di rawa banjiran sungai Batanghari (Nurdawati et al., 2006), rawa banjiran Sungai Kampar Riau (Simanjuntak et al., 2006), Waduk Koto Panjang (Warsa et al., 2008) dan Danau Singkarak (Azrita, 2011). Menurut Wilson \& Clarke (1996), dengan berkurangnya kepadatan stok populasi dan mengecilnya ukuran ikan dapat menurunkan seleksi genetik, potensi fekunditas, berkurangnya rata-rata ikan memijah, tidak seimbangnya sex ratio, dan kehilangan variasi genetik. Ruzafa et al. (1996) menyatakan proteksi penangkapan dapat meningkatkan heterozigositas ikan dan memulihkan populasi ikan dari ancaman kepunahan.

Pengkajian fekunditas ikan bujuk sangat penting dilakukan karena akan menentukan potensi benih untuk proses domestikasi dan budidaya. Fekunditas berhubungan dengan panjang total dan bobot badan ikan (Azrita et al., 2010). Variasi lingkungan, terutama ketersediaan makanan di habitatnya berperanan penting terhadap kualitas telur dan waktu reproduksi ikan (Reidel et al., 2010), kekurangan makanan dapat menyebabkan tertundanya pematangan gonad dan rendahnya fekunditas (Schreck et al., 2001 ; Johnston et al., 2007). Makanan bagi ikan dapat merupakan faktor yang menentukan bagi kepadatan populasi, pertumbuhan, dan kondisi ikan, sedangkan macam makanan satu spesies ikan biasanya tergantung pada umur, tempat, waktu, dan alat pencernaan dari ikan itu sendiri (Prianto \& Suryanti, 2009). Dengan mengetahui kebiasaan makanan satu jenis ikan dapat dilihat hubungan ekologi antara ikan dengan organisme lain yang ada di suatu perairan, misalnya bentuk-bentuk pemangsaan, saingan, dan rantai makanan.

Beberapa penelitian tentang fekunditas dan diameter telur sudah dilakukan terhadap ikan marga Channa antara lain fekunditas ikan Spotted snakehead (Channa punctata) di India berkisar 2.300-29.600 butir (Jhingran, 1984), diameter telur 2 mm (Khan, 1924 dalam Courtenay \& Williams, 2004), fekunditas dwarf snakehead (Channa gachua) di Berhampur India berkisar antara 2.539-7.194 butir, diameter telur 2,1-2,6 mm (Mishra, 1991), fekunditas ikan chevron snakehead (Channa striata) di Malaysia berkisar 3.000-30.000 butir, diameter telur 1,25 mm (Jhingran, 1984), fekunditas ikan chevron snakehead (Channa striata) di rawa banjiran Sungai Musi berkisar 1.141-16.468 butir (Makmur et al., 2003). Fekunditas ikan cobra snakehead (Channa marulius) berkisar 2.000-40.000 butir (Lee \& Ng, 1991) dan diameter telur ikan Northern snakehead (Channa argus) berkisar 1,80-1,85 mm (Son, 1960 dalam Courtenay \& Williams, 2004).

Dari beberapa fekunditas spesies ikan tersebut di atas, ternyata penelitian tentang fekunditas ikan bujuk (Channa lucius) belum ada, maka dibutuhkan data aspek reproduksi dan makanan ikan bujuk. Tujuan dari kajian fekunditas, diameter telur, dan kebiasaan makanan menjadi fokus pada penelitian ini untuk menganalisis kemampuan ikan bujuk menghasilkan telur dan ukuran telurnya, serta makanan utama dan pelengkap setiap habitat, sejalan dengan pengelolaan ikan bujuk untuk domestikasi dan budidayanya. Informasi ini dapat digunakan untuk memprediksi fekunditas, diameter telur, dan makanan. 


\section{BAHAN DAN METODE}

Penelitian ini dilakukan di Danau SingkarakSumatera Barat, Rawa Banjiran Pematang Lindung Tanjung Jabung Timur-Jambi, dan rawa banjiran Desa Mentulik Kampar-Riau. Data sampel ikan bujuk dikumpulkan pada bulan Januari, Juni, dan November 2010. Pengambilan sampel ikan dari setiap lokasi penelitian masing-masing sebanyak 10 ekor setiap waktu pengambilan sampel sehingga berjumlah 30 ekor setiap habitat (Gambar 1) dengan menggunakan alat tangkap bubu dan pancing. Titik pengambilan sampel dipilih berdasarkan kepada lokasi tempat penangkapan ikan bujuk yang sering dilakukan oleh nelayan. Posisi lokasi penelitian setiap habitat ditentukan dengan alat Garmin's GPSMAP tipe 60CSx Sensors and maps dan kriteria habitat dicantumkan pada Tabel 1 .

Contoh ikan bujuk dimasukkan ke dalam wadah steroform ukuran $120 \mathrm{~cm} \times 50 \mathrm{~cm} \times 40$ $\mathrm{cm}$ secara terpisah, selanjutnya diangkut ke Laboratorium Terpadu Fakultas Perikanan dan Ilmu Kelautan, Universitas Bung Hatta, Padang. Di laboratorium, contoh ikan diukur panjang total $(\mathrm{mm})$ dengan mistar ukur ketelitian 1,0 $\mathrm{mm}$ dan ditimbang bobot $(\mathrm{g})$ dengan timbangan elektronik merek Shimadzu ketelitian 0,1 g. Selanjutnya ikan dibedah pada bagian perut untuk diamati organ reproduksi (gonad) dan penentuan tingkat kematangan gonad (TKG). Pengamatan TKG secara morfologi didasarkan atas klasifikasi yang dimodifikasi dari Syandri (1996). Lewat tahapan ini maka dapat diketahui ikan bujuk betina pada TKG III atau IV yang merupakan ikan yang mengandung telur. Fekunditas dihitung dari ikan betina TKG IV, sedangkan diameter telur diukur dari TKG III dan IV, diameter telur pada bagian anterior, dan posterior hanya diukur pada TKG IV.
Penghitungan fekunditas dilakukan dua tahap, tahap pertama adalah mendapatkan telur yaitu mengambil telur dari induk ikan dengan mengangkat seluruh gonadnya dari dalam perut dan tahap kedua cara menghitung telur yaitu dengan menggunakan metode gravimetrik (Effendie, 1978), bobot gonad setiap ekor ikan ditimbang dalam satuan gram dan sub gonad ditimbang sebanyak 1 gram untuk menentukan jumlah telur. Bagian sub gonad adalah anteroir dan posterior dari gonad yang kemudian diambil telur-telurnya dan diawetkan dengan larutan Gilson yang bertujuan untuk mengeraskan telur dan melepaskan telur dari jaringan ovari. Larutan Gilson terdiri atas: $100 \mathrm{~mL}$ alkohol $60 \%, 880$ $\mathrm{mL}$ akuades, $15 \mathrm{~mL}$ asam nitrit, $18 \mathrm{~mL}$ asam asetat glasial, dan $20 \mathrm{~g}$ mercuri klorida (Bagenal dalam Effendie, 1979). Data telur dipergunakan untuk perhitungan fekunditas dengan formula:

$$
\frac{F}{t}=\frac{B}{b}
$$

di mana:

$\mathrm{F}=$ Fekunditas total

$\mathrm{t}=$ Jumlah telur dari contoh gonad $(\mathrm{g})$

$\mathrm{B}=$ Bobot gonad seluruhnya $(\mathrm{g})$

$\mathrm{b}=$ Bobot contoh gonad $(\mathrm{g})$

Untuk menduga fekunditas mutlak berdasarkan panjang total dan bobot badan dicari pula hubungan antara fekunditas dengan panjang total dan bobot badan masing-masing dinyatakan dengan persamaan Ricker (1975) sebagai berikut:

$$
\begin{aligned}
& F=a L^{b} \text { atau } \log F=\log a+b \log L \\
& F=a B t^{2} \text { atau } L \log F=\log a+b \log W
\end{aligned}
$$

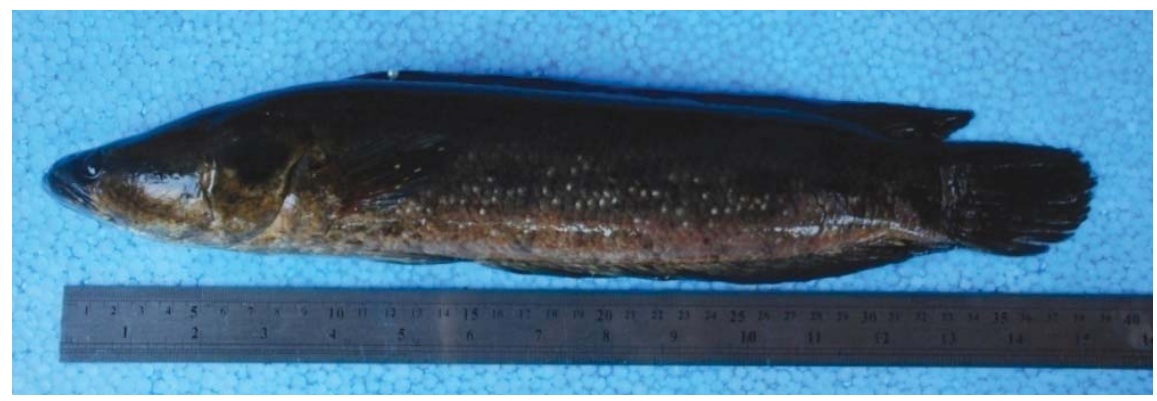

Gambar 1. Ikan bujuk (Channa lucius)

Figure 1. Bujuk fish (Channa lucius) 
Tabel 1. Deskripsi habitat perairan pengambilan sampel ikan bujuk

Table 1. Description of aquatic habitats of bujuk fish sampling

\begin{tabular}{|c|c|c|}
\hline $\begin{array}{l}\text { Habitat } \\
\text { Habitats }\end{array}$ & $\begin{array}{l}\text { Posisi } \\
\text { Position }\end{array}$ & $\begin{array}{l}\text { Deskripsi/Ket erangan } \\
\text { Description/Rem ark }\end{array}$ \\
\hline $\begin{array}{l}\text { Danau (Lake) } \\
\text { Singkarak } \\
\text { Kabupaten (District) } \\
\text { Tanah Datar dan } \\
\text { (and) Kabupaten } \\
\text { (District) Solok, } \\
\text { Sumatera Barat }\end{array}$ & $\begin{array}{l}100^{\circ} 26^{\prime} 15^{\prime \prime}-101^{\circ} 31^{\prime} 46^{\prime \prime} \text { BT } \\
\text { dan (and) } \\
00^{\circ} 31^{\prime} 46^{\prime \prime}-00^{\circ} 42^{\prime} 20^{\prime \prime} \text { LS }\end{array}$ & 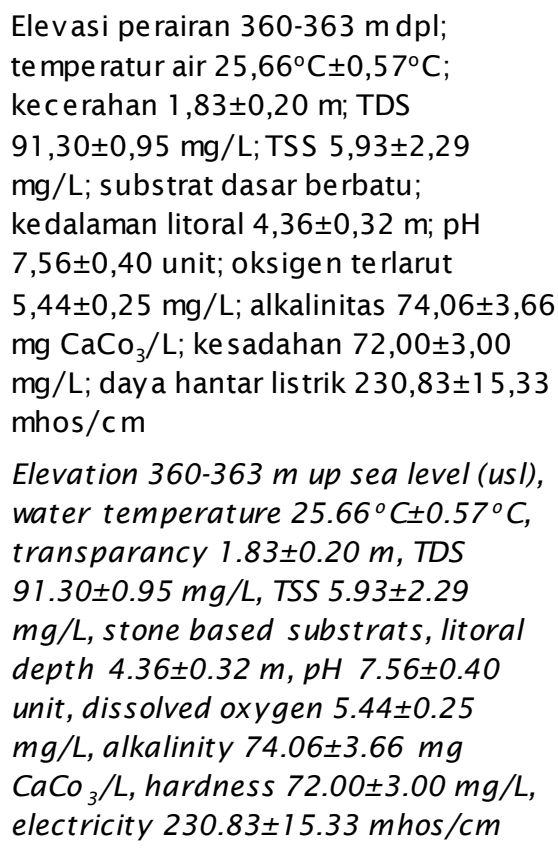 \\
\hline $\begin{array}{l}\text { Rawa (Swamp) } \\
\text { Banjiran Desa } \\
\text { (Village) Pematang } \\
\text { Lindung Kabupaten } \\
\text { (District) Tanjung } \\
\text { Jabung Timur, Jambi }\end{array}$ & $\begin{array}{l}108^{\circ} 24^{\prime} 20^{\prime \prime}-108^{\circ} 25^{\prime} 20^{\prime \prime} \text { BT } \\
\text { dan (and) } \\
00^{\circ} 16^{\prime} 60^{\prime \prime}-00^{\circ} 27^{\prime} 21^{\prime \prime} \text { LS }\end{array}$ & 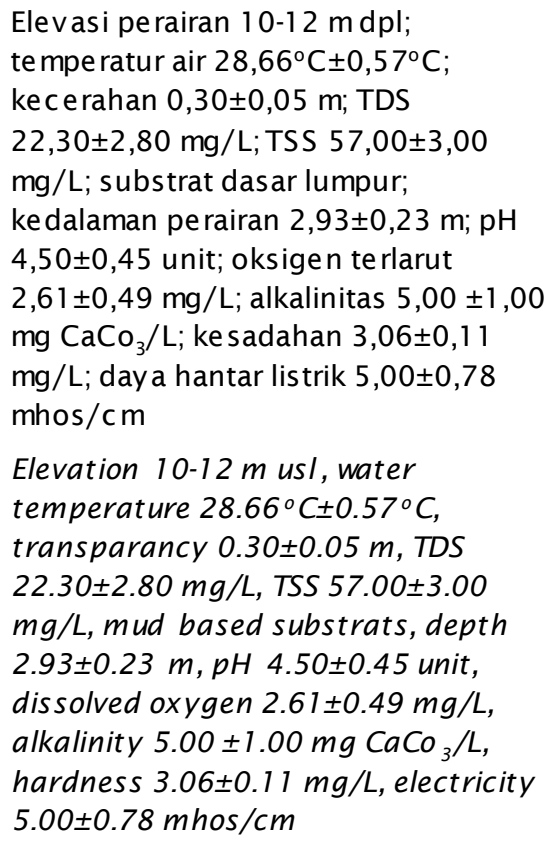 \\
\hline
\end{tabular}


Lanjutan Tabel 1 (Table 1 continued)

\begin{tabular}{|c|c|c|}
\hline $\begin{array}{l}\text { Habitat } \\
\text { Habitats }\end{array}$ & $\begin{array}{l}\text { Posisi } \\
\text { Position }\end{array}$ & $\begin{array}{l}\text { Deskripsi/Ket erangan } \\
\text { Description/Remark }\end{array}$ \\
\hline $\begin{array}{l}\text { Rawa (Swamp) } \\
\text { Banjiran Desa } \\
\text { (Village) Mentulik } \\
\text { Kabupaten (District) } \\
\text { Kampar, Riau }\end{array}$ & $\begin{array}{l}101^{\circ} 23^{\prime} 64^{\prime \prime}-101^{\circ} 24^{\prime} 13^{\prime \prime} \text { BT } \\
\text { dan (and) } \\
00^{\circ} 11^{\prime} 13^{\prime \prime}-00^{\circ} 09^{\prime} 32^{\prime \prime} \text { LS }\end{array}$ & 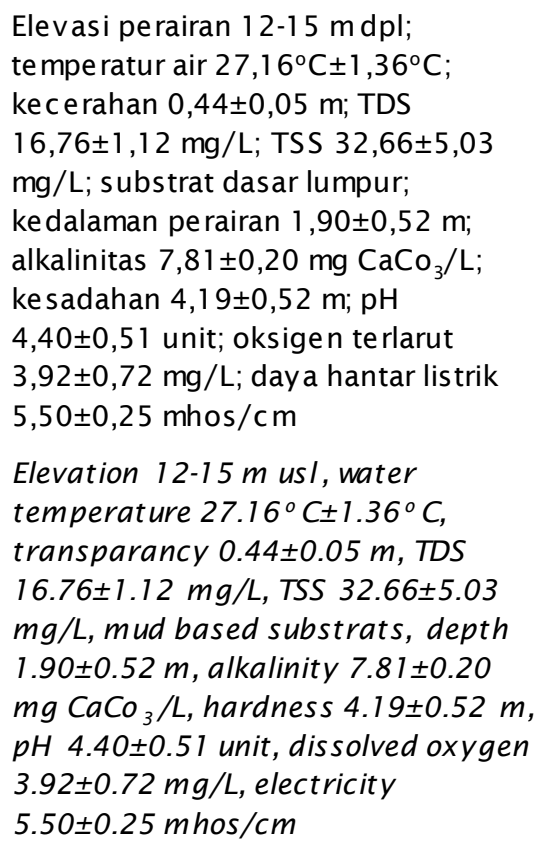 \\
\hline
\end{tabular}

di mana:

$\mathrm{F}=$ Fekunditas (butir)

$\mathrm{L}=$ Panjang total ikan (mm)

$\mathrm{Bt}=$ Bobot badan ikan $(\mathrm{g})$

$\mathrm{a}$ dan $\mathrm{b}=$ Konstanta

Untuk mendapatkan informasi tentang jenis makanan ikan bujuk dari tiga kelompok ukuran yaitu ukuran 100-200 mm, ukuran 201-300 mm, dan ukuran 301-400 mm, diambil masingmasing sebanyak 30 ekor ikan contoh dari Danau Singkarak, rawa banjiran Desa Pematang Lindung-Jambi, dan rawa banjiran Desa Mentulik Kampar-Riau. Ikan contoh yang diperoleh diambil alat pencernaannya dan disimpan dalam wadah yang berlabel. Selanjutnya diawetkan dengan formalin $10 \%$ dan dianalisis isi lambungnya. Identifikasi organisme makanan yang dimakan oleh ikan bujuk diamati dengan mata telanjang dan bantuan mikroskop.

Analisis jenis makanan digunakan indeks bagian terbesar (index of preponderance) merupakan gabungan dari dua metode yaitu metode frekuensi kejadian dan metode volumetrik. Metode ini dikembangkan oleh Natarajan \& Jhingran (1961) dalam Effendie (1979) dengan rumus:

$$
\mathrm{IP}(\%)=\frac{\mathrm{Vi} \times \mathrm{Oi}}{\sum_{\mathrm{i} 1}^{\mathrm{n}}(\mathrm{Vi} \times \mathrm{Oi})} \times 100 \%
$$

di mana:

IP = Indeks bagian terbesar (index of preponderance)

$\mathrm{Vi}=$ Persentase volume makanan ikan jenis ke-i

$\mathrm{Oi}=$ Persentase frekuensi kejadian makanan jenis ke-i

$\mathrm{n}$ = Jumlah organisme makanan

\section{HASIL DAN BAHASAN}

\section{Fekunditas}

Terdapat variasi fekunditas ikan bujuk antar lokasi penelitian (Tabel 2), fekunditas total ikan bujuk pada kisaran panjang total 194$400 \mathrm{~mm}$ dan bobot badan 236-227 g berkisar 1.152-3.746 butir per ekor. Nilai tersebut 
Tabel 2. Variasi fekunditas ikan bujuk dari habitat berbeda $(\mathrm{n}=30)$

Table 2. Fecundity variation of bujuk fish from different habitats $(n=30)$

\begin{tabular}{|c|c|c|c|c|c|c|}
\hline \multirow{2}{*}{$\begin{array}{l}\text { Lokasi } \\
\text { Location }\end{array}$} & \multicolumn{2}{|c|}{$\begin{array}{c}\text { Panjang total } \\
\text { Total length }(\mathrm{mm})\end{array}$} & \multicolumn{2}{|c|}{$\begin{array}{l}\text { Bobot badan } \\
\text { Body weight }(\mathrm{g})\end{array}$} & \multicolumn{2}{|c|}{$\begin{array}{l}\text { Jumlah telur (but ir)/ekor } \\
\text { Number of eggs/pcs }\end{array}$} \\
\hline & $\begin{array}{c}\text { Kisaran } \\
\text { Range }\end{array}$ & $\begin{array}{c}\text { Rataan } \pm S D \\
\text { Average } \pm S D\end{array}$ & $\begin{array}{c}\text { Kisaran } \\
\text { Range }\end{array}$ & $\begin{array}{c}\text { Rat aan } \pm S D \\
\text { Average } \pm S D\end{array}$ & $\begin{array}{c}\text { Kisaran } \\
\text { Range }\end{array}$ & $\begin{array}{c}\text { Rataan } \pm S D \\
\text { Average } \pm S D\end{array}$ \\
\hline $\begin{array}{l}\text { Danau (Lake) } \\
\text { Singkarak } \\
\text { Rawa (Swamp) }\end{array}$ & 194-299 & $281.70 \pm 28.5$ & $120.6-338.0$ & $236.9 \pm 59.4$ & $1,152-3,002$ & $1,996 \pm 568^{a}$ \\
\hline $\begin{array}{l}\text { Banjiran P. } \\
\text { Lindung, Jambi } \\
\text { Rawa (Swamp) }\end{array}$ & $240-292$ & $297.96 \pm 37.2$ & $200.3-489.5$ & $327.4 \pm 117.3$ & $1,155-3,746$ & $2,196 \pm 866^{b}$ \\
\hline $\begin{array}{l}\text { Banjiran } \\
\text { Mentulik, Riau }\end{array}$ & $245-400$ & $298.03 \pm 37.5$ & $156.0-560.0$ & $276.8 \pm 88.5$ & $1,293-3,710$ & $2,539 \pm 716^{c}$ \\
\hline
\end{tabular}

Keterangan (Note):

Angka superscrip yang berbeda di belakang angka rataan fekuditas menunjukkan berbeda nyata $(P<0,05)$ Different superscrip number at the behind of average value of fecundity showed significant differences $(P<0.05)$

menunjukkan potensi telur yang dihasilkan untuk satu kali pemijahan.

Dari data Tabel 2 dapat dinyatakan bahwa pada ukuran rataan panjang total yang mendekati sama yaitu berkisar 281,70-298,03 mm antara habitat perairan terdapat perbedaan fekunditas ikan bujuk secara nyata $(P<0,05)$. Rataan fekunditas tertinggi terdapat pada populasi ikan bujuk dari perairan rawa banjiran Desa Mentulik Kabupaten Kampar-Riau, sedangkan yang terendah dari Danau Singkarak. Perbedaan fekunditas tersebut dapat disebabkan oleh perbedaan genetik ikan bujuk antar populasi, yaitu ikan bujuk dari rawa banjiran Mentulik Kampar-Riau mempunyai nilai rataan heterozigositas lebih tinggi yaitu 0,3668 , jika dibandingkan dengan populasi ikan bujuk dari rawa banjiran Desa Pematang Lindung Tanjung Jabung Timur-Jambi dengan nilai heterozigositas 0,3449 dan dari Danau Singkarak dengan nilai heterozigositas 0,2186 (Azrita et al., 2011). Menurut Wilson \& Clarke (1996), nilai heterozigositas yang rendah akan menyebabkan rendahnya fekunditas ikan.

Hubungan fekunditas mutlak dengan panjang total dan bobot badan ikan bujuk dari setiap habitat perairan berdasarkan persamaan geometrik disajikan pada Tabel 3 dan Gambar 2 dan 3.
Nilai koefisien determinasi $\left(R^{2}\right)$ yang diperoleh memperlihatkan bahwa nilai $R^{2}$ hubungan fekunditas dengan panjang total untuk ketiga habitat berkisar $0,56-0,67$; artinya 56\%-67\% fekunditas ditentukan oleh panjang total, sedangkan untuk hubungan fekunditas dengan bobot badan nilai koefisien determinasi $\left(R^{2}\right)$ berkisar $0,45-0,55$; artinya $45 \%-55 \%$ fekunditas ditentukan oleh bobot badan. Keadaan ini mencerminkan bahwa parameter panjang badan lebih baik untuk pendugaan fekunditas ikan bujuk.

Potensi fekunditas berdasarkan nilai dugaan panjang total dari persamaan geometrik hubungan panjang dengan fekunditas (Tabel 3), jika panjang ikan bujuk setiap habitat $250 \mathrm{~mm}$ maka fekunditas dugaan ikan bujuk dari Danau Singkarak 1.337 butir, dari rawa banjiran Desa Pematang Lindung-Jambi 1.399 butir dan dari rawa banjiran Desa Mentulik Kampar-Riau 1.920 butir. Dapat dinyatakan bahwa dengan panjang yang sama maka fekunditas ikan bujuk dari rawa banjiran Desa Mentulik Kampar-Riau mempunyai fekunditas lebih banyak.

Perbedaan fekunditas ikan bujuk dari setiap habitat dapat pula disebabkan oleh ketersediaan makanan di perairan tersebut. Di Danau Singkarak keragaman ikan hanya 19 
Tabel 3. Persamaan geometrik hubungan panjang badan dan bobot badan dengan fekunditas

Table 3. Geometric equation of the correlation between body length and body weight with fecundity

\begin{tabular}{lcccccc}
\hline \multicolumn{1}{c}{ Lokasi (Location) } & $\mathbf{F}=\mathbf{a ~ L ^ { \mathbf { b } }}$ & $\mathbf{R}^{2}$ & $\mathbf{n}$ & $\mathbf{F}=\mathbf{a} \mathbf{W}^{\mathbf{b}}$ & $\mathbf{R}^{2}$ & $\mathbf{n}$ \\
\hline $\begin{array}{l}\text { Danau (Lake) Singkarak, } \\
\text { Sumatera Barat (West Sumatra) }\end{array}$ & $\mathrm{F}=0.00038 . \mathrm{L}^{2.730}$ & 0.67 & 30 & $\mathrm{~F}=16.1808 . \mathrm{W}^{0.875}$ & 0.55 & 30 \\
$\begin{array}{l}\text { Rawa (Swamp) Banjiran } \\
\begin{array}{l}\text { Pematang Lindung, Jambi } \\
\text { Rawa (Swamp) Banjiran }\end{array}\end{array}$ & $\mathrm{F}=0.3258 . \mathrm{L}^{1.515}$ & 0.56 & 30 & $\mathrm{~F}=147.2312 . \mathrm{W}^{0.444}$ & 0.45 & 30 \\
Mentulik, Riau & $\mathrm{F}=0.2437 . \mathrm{L}^{1.625}$ & 0.62 & 30 & $\mathrm{~F}=76.7361 . \mathrm{W}^{0.617}$ & 0.45 & 30 \\
\hline
\end{tabular}

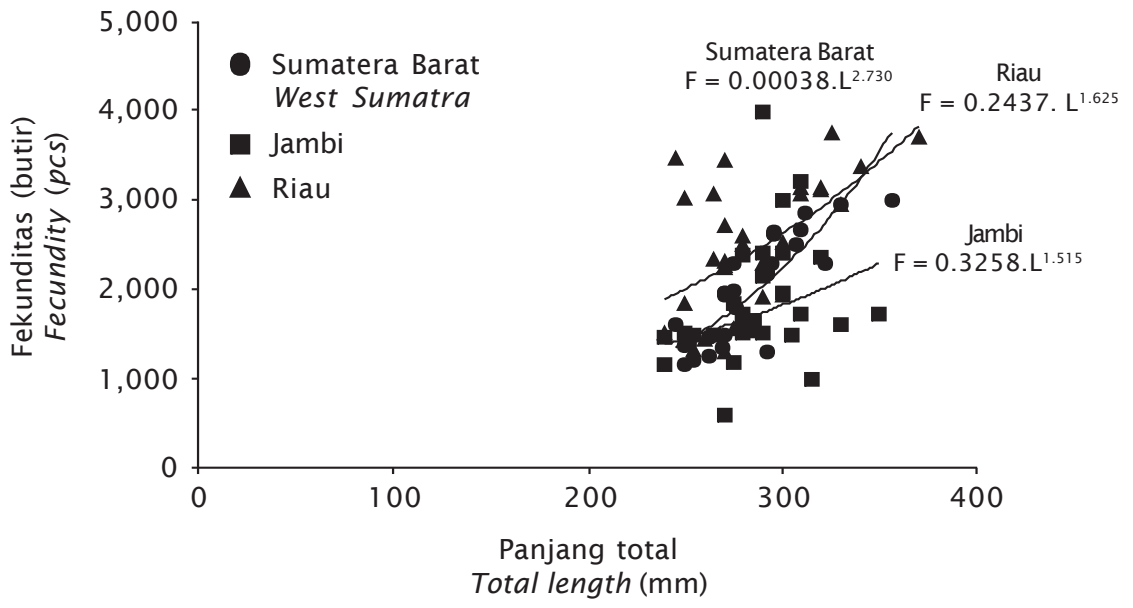

Gambar 2. Hubungan fekunditas dengan panjang total ikan bujuk

Figure 2. Correlation between fecundity and total length of bujuk fish

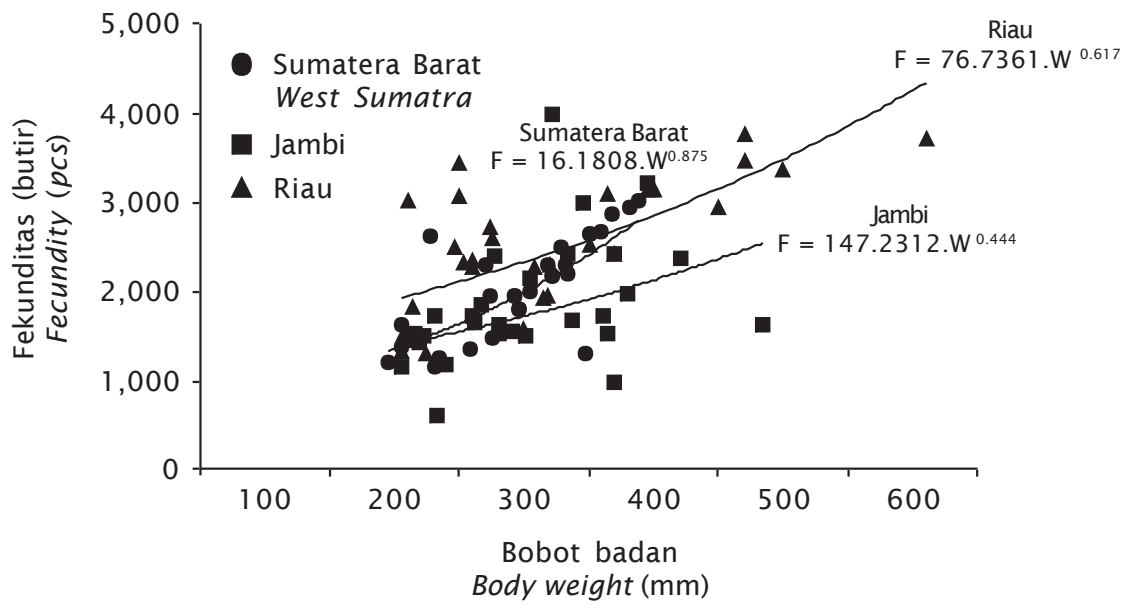

Gambar 3. Hubungan fekunditas dengan bobot badan ikan bujuk

Figure 3. Correlation between fecundity and body weight of bujuk fish 
spesies (Syandri, 2008), di Sungai Batanghari dan rawa banjirannya 162 spesies (Nurdawati, 1995), di Sungai Kampar dan rawa banjirannya 86 spesies (Simanjuntak et al., 2006). Semakin banyak spesies ikan di suatu badan air, diduga semakin banyak spesies ikan yang dapat dimakan oleh ikan bujuk sehingga dapat meningkatkan jumlah fekunditas. Sejauh mana pengaruh jenis spesies ikan yang dimakan oleh ikan bujuk terhadap fekunditas dalam penelitian ini belum dapat diungkapkan.

\section{Diameter Telur}

Diameter telur ikan bujuk tingkat kematangan gonad (TKG) III dan IV dari Danau Singkarak, Sumatera Barat, rawa banjiran Desa Pematang Lindung Tanjung Jabung TimurJambi, dan rawa banjiran Desa Mentulik KamparRiau dicantumkan pada Tabel 4.

Diameter telur ikan bujuk TKG III dan TKG IV berbeda nyata antar lokasi penelitian. Rataan diameter telur ikan bujuk TKG IV yang berasal dari rawa banjiran Desa Mentulik Kabupaten Kampar Provinsi Riau lebih besar $(1,70 \pm 0,14 \mathrm{~mm})$ daripada diameter telur ikan bujuk TKG IV dari rawa banjiran Desa Pematang Lindung Kabupaten Tanjung Jabung Timur Provinsi Jambi $(1,53 \pm 0,11 \mathrm{~mm})$ dan Danau Singkarak, Sumatera Barat (1,35 $\pm 0,09 \mathrm{~mm})$. Perbedaan tersebut dapat disebabkan oleh perbedaan genetik antar populasi. Genetik populasi ikan bujuk berdasarkan nilai heterozigositas dari rawa banjiran Desa Mentulik Kampar-Riau lebih unggul daripada populasi rawa banjiran Desa Mentulik Kampar dan populasi Danau Singkarak (Azrita et al., 2011).

Makanan yang tersedia dapat pula menyebabkan perbedaan diameter telur antara habitat perairan. Ikan bujuk yang bersifat karnivora mempunyai kemampuan untuk memakan spesies ikan yang hidup di habitatnya. Di rawa banjiran Desa Pematang Lindung Tanjung Jabung Timur-Jambi dan rawa banjiran Desa Mentulik Kampar-Riau mempunyai keanekaragaman spesies yang lebih banyak (Nurdawati, 1995; Simanjuntak et al., 2006). Diduga semakin banyak keanekaragaman spesies ikan yang dimakan akan mempengaruhi terhadap diameter tekur ikan bujuk. Syandri \& Effendie (1997) menyatakan perbedaan diameter telur ikan bilih dapat disebabkan oleh ketersediaan makanan di alam. Diameter telur ikan bujuk hampir sama ukurannya dengan diameter telur ikan Channa argus berkisar 1,8-1,85 mm (Soin, 1960 dalam Courtenay \& Williams, 2004), diameter telur ikan Channa blehari berkisar 0,9-1,1 mm (Courtenay \& Williams, 2004), diameter telur ikan Channa gachua berkisar 2,1-2,6 mm (Mishra, 1991).

Tabel 4. Diameter telur ikan bujuk berdasarkan TKG dan lokasi penelitian

Table 4. Egg diameter of bujuk fish based on the gonada development and research location

\begin{tabular}{|c|c|c|c|c|c|c|}
\hline \multirow{3}{*}{$\begin{array}{l}\text { Lokasi } \\
\text { Location }\end{array}$} & \multirow{2}{*}{\multicolumn{2}{|c|}{$\begin{array}{c}\text { Diamet er telur } \\
\text { Egg diameter }(\mathrm{mm}) \\
\text { TKG III } \\
\text { ISG III }\end{array}$}} & \multirow{3}{*}{$\mathbf{n}$} & \multirow{2}{*}{\multicolumn{2}{|c|}{$\begin{array}{c}\text { Diameter telur } \\
\text { Egg diameter }(\mathrm{mm}) \\
\text { TKG IV } \\
\text { ISG IV }\end{array}$}} & \multirow{3}{*}{$\mathbf{n}$} \\
\hline & & & & & & \\
\hline & $\begin{array}{l}\text { Kisaran } \\
\text { Range }\end{array}$ & $\begin{array}{l}\text { Rataan } \\
\text { Average }\end{array}$ & & $\begin{array}{l}\text { Kisaran } \\
\text { Range }\end{array}$ & $\begin{array}{l}\text { Rataan } \\
\text { Average }\end{array}$ & \\
\hline $\begin{array}{l}\text { Danau (Lake) Singkarak, } \\
\text { Sumatera Barat (West Sumatra) }\end{array}$ & $1.00-1.30$ & $1.12 \pm 0.09^{a}$ & 50 & $125-155$ & $1.35 \pm 0.09^{a}$ & 50 \\
\hline $\begin{array}{l}\text { Rawa (Swamp) Banjiran } \\
\text { Pematang Lindung, Jambi }\end{array}$ & $1.15-1.36$ & $1.28 \pm 0.25^{b}$ & 50 & $1.32-170$ & $1.53 \pm 0.11^{\mathrm{b}}$ & 50 \\
\hline $\begin{array}{l}\text { Rawa (Swamp) Banjiran } \\
\text { Mentulik, Riau }\end{array}$ & $1.17-1.42$ & $1.32 \pm 0.06^{c}$ & 50 & $1.40-1.90$ & $1.70 \pm 0.14^{c}$ & 50 \\
\hline
\end{tabular}

Keterangan (Note):

Angka superscrip yang berbeda di belakang angka rataan setiap TKG menunjukkan berbeda nyata $(\mathrm{P}<0,05)$ (Different superscrip number at the behind of average value of ISG showed significant differences $(P<0.05))$ 
Selanjutnya kelompok ukuran diameter telur TKG IV berbeda antara bagian anterior dan posterior di dalam ovarium, hal ini menunjukkan bahwa perkembangan oosit ikan bujuk bersifat sinkronisme kelompok (par groups) yaitu sedikitnya ditemukan dua populasi oosit yang berbeda pada satu tingkat perkembangan gonad. Berdasarkan tipe perkembangan oosit tersebut maka tipe pemijahan ikan bujuk adalah partial spawner yaitu spesies ikan yang tidak mengeluarkan telur matang sekaligus pada satu kali pemijahan, berpijah di sungai dikaitkan dengan tingginya permukaan air akibat hujan atau banjir. Pada ikan gabus (Channa striata) ditemukan pula diameter telur yang berbeda secara mencolok antara anterior dan posterior pada TKG IV dan berdasarkan perbedaan tersebut, maka sifat pemijahan ikan gabus adalah parsial (Makmur et al., 2003). Menurut Lowe-Mc Coonell (1975), tipe pemijahan parsial yaitu adaptasi yang menguntungkan bagi reproduksi ikan yang berpijah di sungai dikaitkan dengan fluktuasi tingginya permukaan air akibat hujan atau banjir dan pada waktu tersebut makanan sangat berlimpah. Di antara spesies ikan tipe parsial terdapat spesies ikan yang melindungi telur yang telah dipijahkan dan biasanya fekunditas ikan tersebut lebih kecil jika dibandingkan dengan ikan tipe pemijahan yang sama tetapi tidak melindungi telur.

Dari hasil penelitian dapat dinyatakan bahwa ukuran telur ikan bujuk termasuk besar dan telur yang besar akan cenderung memiliki bukaan mulut larva yang besar sehingga memudahkan untuk menerima pakan alami seperti nauplii Artemia salina ketika perubahan makanan dari endogenous feeding ke exogenous feeding. Pendapat ini berdasarkan hasil penelitian Syandri et al. (2004) terhadap ikan garing (Tor douronensis) yang menetaskan larva ukuran 1,1 mm pada umur empat hari langsung dapat memakan nauplii Artemia salina sebagai pakan alaminya sehingga sintasan larva dapat mencapai $80 \%$. Berbeda dengan larva ikan bilih yang baru menetas mempunyai ukuran 0,2-0,3 mm; sangat sulit untuk memberikan pakan alami dan pada umur 13 hari baru dapat memakan nauplii Artemia salina, akibat dari itu sintasan larva ikan bilih hingga umur 14 hari hanya 30\% (Syandri, 1997). Dalam penelitian ini ukuran larva dan bukaan mulut larva ikan bujuk yang baru menetas belum dapat diungkapkan. Oleh karena itu, diperlukan penelitian domestikasi dan pembenihan ikan bujuk sehingga ukuran dan bukaan mulut larva dapat diketahui sehingga memudahkan dalam pemeliharaan benih sebagai calon ikan budidaya.

Berdasarkan pengamatan di lapangan ikan bujuk hidup pada air tenang di rawa banjiran sepanjang sungai dan perairan danau, bersembunyi di bawah tanaman air pada siang hari, malam hari ditemukan aktif mencari makan. Berdasarkan hal tersebut, ikan bujuk untuk bertelur membuat sarang pada perairan dangkal dengan arus lemah sebagai habitat pemijahan. Penulis bersama nelayan menemukan larva ikan bujuk di bawah tanaman air dan belukar terendam air. Ikan gabus (Channa striata) satu marga dengan ikan bujuk membuat sarang yang berbentuk busa di sekitar tanaman air di rawa, busa tersebut berbentuk semacam lingkaran yang berfungsi sebagai pelindung telur (Muflikhah, 2007).

\section{Kebiasaan Makanan}

Berdasarkan analisis kebiasaan makanan dengan metode indeks, bagian terbesar terhadap tiga kelompok ukuran panjang total ikan bujuk yaitu kelompok pertama ukuran 100200 mm, kelompok kedua 201-300 mm, dan kelompok ketiga 301-400 mm masing-masing 30 ekor ikan sampel setiap kelompok ukuran terbukti semakin panjang ukuran ikan bujuk maka persentase makanan utama berupa ikan semakin tinggi, diikuti oleh udang, anak katak, dan serangga air seperti dicantumkan pada Gambar 4.

Makanan utama ikan bujuk pada tiga kelompok ukuran dan habitat berbeda adalah ikan dengan kisaran nilai indeks bagian terbesar 70,78\%-89,01\%; makanan pelengkap adalah udang dengan kisaran indeks bagian terbesar 5,81\%-16,3\%; dan anak katak 1,77\%-3,28\%. Berdasarkan hal tersebut ikan bujuk dapat dikelompokkan kepada ikan karnivora murni bersifat predator (Gambar 5). Spesies ikan yang dimakan oleh ikan bujuk dari analisis isi lambung adalah ikan seluang (Rasbora sp.), betok (Anabas testudinae), tambakan (Helostema temmincki), sepat rawa (Trichogaster trichopterus). Sama halnya dengan makanan utama ikan gabus (Channa striata) adalah ikan dengan rataan indeks bagian terbesar $87,79 \%$ dibandingkan dengan jenis makanan lain. Spesies ikan tersebut di atas merupakan spesies yang banyak terdapat di perairan rawa banjiran yang juga merupakan habitat utama ikan gabus (Makmur et al., 2003). 


\section{Ukuran ikan 100-200 mm}

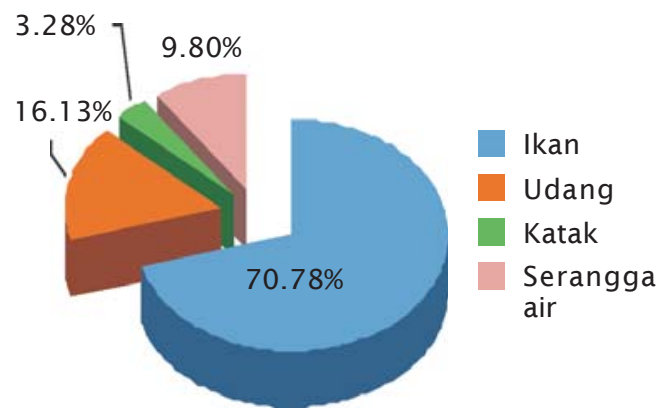

Ukuran ikan 201-300 mm

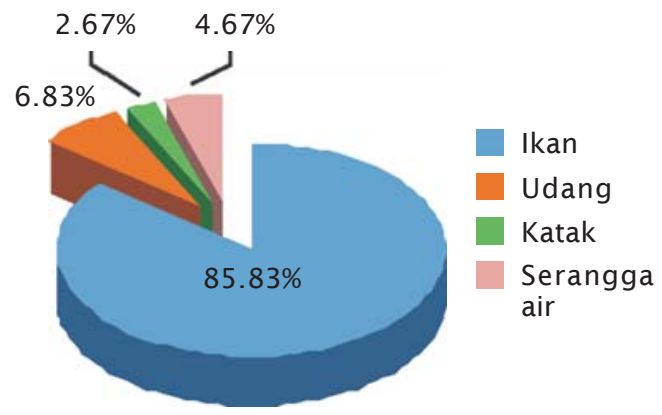

Ukuran ikan 301-400 mm

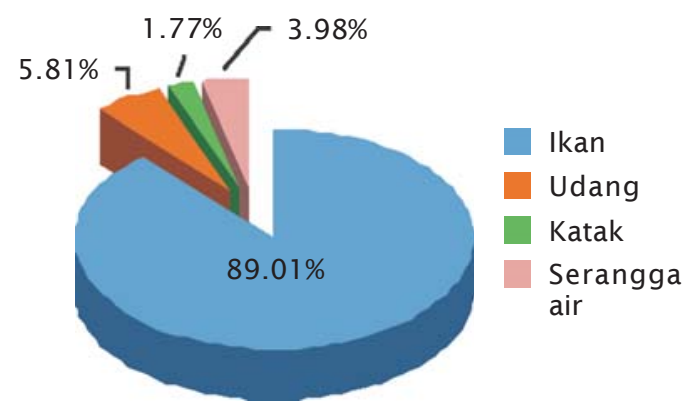

Gambar 4. Histogram nilai rataan Index of Preponderance (\%) ikan bujuk berdasarkan kelompok ukuran

Figure 4. Histogram of average value of Index Preponderance (\%) for bujuk fish based on the fish size
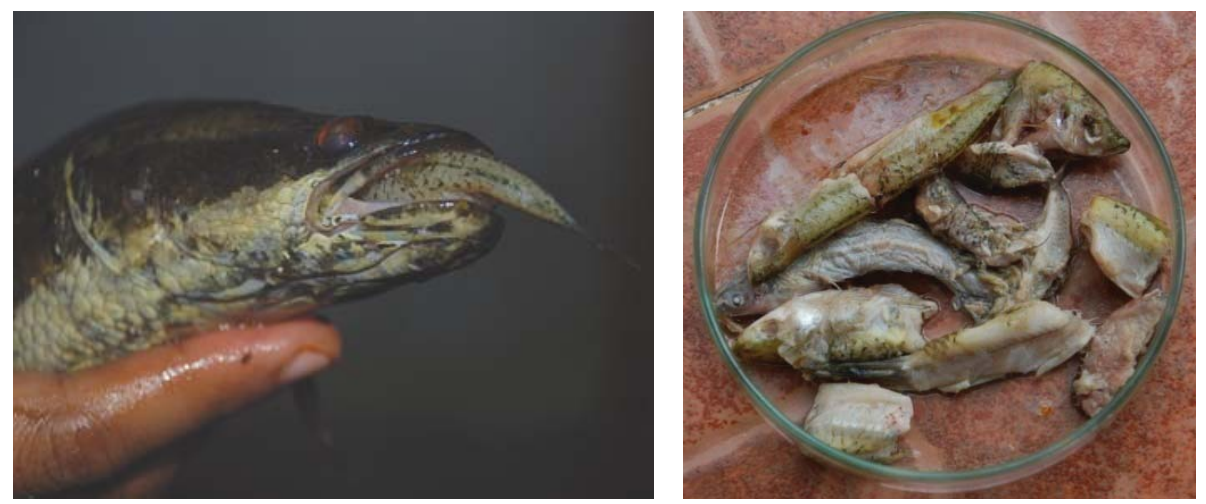

Gambar 5. Salah satu jenis makanan ikan bujuk

Figure 5. A kind food of bujuk fish

Besarnya persentase dari jenis ikan sebagai makanan utama ikan bujuk tidak terlepas dari sifat ikan tersebut sebagai ikan karnivora murni bersifat predatoryang hidup di perairan sungai dengan rawa banjirannya dan perairan air tawar seperti Danau Singkarak. Pada habitat sungai dan rawa banjirannya memiliki tingkat keanekaragaman spesies yang tinggi (Nurdawati, 1995; Simanjuntak et al., 2006), sedangkan di perairan Danau Singkarak 
relatif rendah (Syandri, 2008). Kebiasaan makanan dan jaringan makanan ditentukan oleh keanekaragaman spesies ikan, interaksi spesies, struktur spesies, dan produktivitas ekosistem (Khan \& Panikhar, 2009). Menurut Lagler et al. (1977), kebiasaan makanan ikan dipengaruhi oleh beberapa faktor antara lain musim, umur ikan, dan ketersediaan makanan pada habitat hidupnya. Hal tersebut terhadap ikan gulamo keken (Johnius belangeri) makanan utamanya adalah udang dan ini tidak terlepas dari habitat utama ikan gulamo keken yang hidup di perairan estuari. Sebagaimana diketahui bahwa di perairan estuari merupakan habitat yang sangat baik bagi pertumbuhan dan perkembangan udang (Prianto \& Suryanti, 2009). Urutan kebiasaan makanan ikan dibedakan ke dalam empat kategori berdasarkan persentase indeks bagian terbesar yaitu makanan utama, makanan pelengkap, makanan tambahan, dan makanan pengganti (Nikolsky, 1963).

Berdasarkan hasil pengukuran panjang usus terhadap 30 ekor ikan bujuk dengan panjang total berkisar 270-350 mm dengan rataan $310 \pm 30,33 \mathrm{~mm}$ dan panjang standar 235-310 mm dengan rataan 274 $27,45 \mathrm{~mm}$; diperoleh panjang usus ikan bujuk berkisar antara 180-240 mm dengan rataan 206 $\pm 24,94$ $\mathrm{mm}$; panjang usus ikan bujuk adalah $75,18 \%$ dari panjang standarnya. Menurut Effendie (1978), ikan karnivora mempunyai usus pendek dikarenakan makanan ikan karnivora adalah daging, sehingga dalam proses pencernaannya tidak memerlukan proses yang lama seperti ikan pemakan tumbuhan.

\section{KESIMPULAN}

1. Terdapat perbedaan fekunditas ikan bujuk pada setiap lokasi penelitian, fekunditas ikan bujuk di Danau Singkarak berkisar 1.152-3.002 butir dengan rataan $1.996 \pm 568$ butir/ekor, rawa banjiran Pematang Lindung-Jambi berkisar 1.155-3.715 dengan rataan $2.196 \pm 866$ butir/ekor dan rawa banjiran Mentulik-Riau berkisar 1.293-3.710 dengan rataan $2.539 \pm 716$ butir/ekor.

2. Ukuran diameter telur ikan bujuk untuk masing-masing lokai, dari Danau Singkarak berkisar 1,25-1,55 mm dengan rataan $1,35 \pm 0,09 \mathrm{~mm}$; rawa banjiran Pematang Lindung-Jambi 1,32-1,70 mm dengan rataan $1,53 \pm 0,11 \mathrm{~mm}$; dan rawa banjiran Mentulik Kampar-Riau 1,40-1,90 mm dengan rataan $1,70 \pm 0,14 \mathrm{~mm}$.
3. Terdapat perbedaan ukuran telur bagian anterior dengan rataan $1,40 \mathrm{~mm}$ dan posterior dengan rataan $1,70 \mathrm{~mm}$; sehingga dinyatakan tipe pemijahan ikan bujuk bersifat partial. Ukuran diameter telur yang akan dipijahkan berkisar antara 1,35-1,70 $\mathrm{mm}$; memijah pada perairan tenang yang ditumbuhi tanaman air, sifat telur merapung di permukaan air dan dijaga oleh induk.

4. Makanan utama ikan bujuk adalah ikan dengan nilai indeks bagian terbesar 70,78\%-89,01\%; makanan pelengkap udang 5,81\%-16,3\% dan anak katak 1,77\%-3,28\%; dan makanan tambahan serangga air. Berdasarkan jenis makanan tersebut ikan bujuk digolongkan kepada ikan karnivora murni bersifat predator dengan panjang usus rata-rata 75,18\% dari panjang standar.

\section{UCAPAN TERIMA KASIH}

Penelitian ini dibiayai dengan Beasiswa Pendidikan Pascasarjana Universitas Andalas Padang, oleh karena itu penulis mengucapkan terima kasih kepada Bapak Novirman Jamarun selaku Direktur Pascasarjana Universitas Andalas, Bapak Dahelmi, Hafrijal Syandri, Estu Nugroho, dan Syaifullah sebagai dosen pembimbing yang telah meluangkan waktu untuk memberikan saran untuk kesempurnaan artikel ini.

\section{DAFTAR ACUAN}

Alawi, H., Rengi, P., \& Tang, U.M. 2008. Direktori ikan komersil di perairan umum Kabupaten Bengkalis, Riau. Unri Press, $53 \mathrm{hlm}$.

Azrita, Syandri, H., \& Aryani, N. 2010. Studi kadar nutrisi telur ikan balingka (Puntius blinka) di Danau Singkarak. Prosiding Seminar Nasional Limnologi IV LIPI di Bogor, hlm. 205-216.

Azrita. 2011 . Potensi ekonomi ikan bujuk (Channa lucius) sebagai peluang calon ikan budidaya di perairan umum daratan. Prosiding Seminar Nasional Forum Perairan Umum Daratan Indonesia, 26-27 September 2011 di Palembang, 325 hlm.

Azrita, Nugroho, E., Syandri, H., Dahelmi, \& Syaifullah. 2011. Variasi genetik ikan bujuk (Channa lucius) dari Sumatera Barat, Jambi dan Riau berdasarkan marker DNA. Berita Biologi, 10(5): 675-680.

Bagenal, T.B. 1978. Aspects of fish fecundity. Ecology of freshwater fish production. Blackwell Scintific Publication. Oxford, p. 75-101. 
Courtenay, W.R., Jr. \& Williams, J.D. 2004. Snakeheads (Pisces, Channidae) A biological synopsis and risk assessment. U.S. Geological Survey Circular, $1251 \mathrm{pp}$.

Effendie, M.I. 1979. Metode Biologi Perikanan. Yayasan Dewi Sri, Bogor.

Gaffar, A.K. \& Nasution, Z. 1990. Upaya Domestifikasi Ikan Perairan Umum. Jurnal Litbang Pertanian, IX(4): 69-75.

Jhingran, A.G. 1984. The fish genetic resources of India: Bureau of Fish Genetic Resources, Allahabad and Maya Press Pvt. Ltd., Allahabad, $82 \mathrm{pp}$.

Johnston, A.T., Wiegand, M.D., Pronyk, R.J., Dyal, S.D., Watchorn, K.E., Kollar, S., \& Casselman, J.M. 2007. Hatching success of walleye embryos in relation to maternal and ova characteristics. Ecology of Freshwater, 16: 295-306.

Khan, M.F. \& Panikkar, P. 2009. Assessment of impacts of invasive fishes on the food web structure and ecosystem properties of a tropical reservoir in India. Ecological Modelling, 220: 2,281-2,290.

Lagler, K.F., Bardach, J.E., Miller, R.R., \& Passino, D.R.M. 1977. Ichthyology. $2^{\text {nd }}$ Ed. New York, John Wiley and Sons, $505 \mathrm{pp}$.

Lee, P.G. \& Ng, P.K.L. 1991. The snakehead fishes of the Indo-Malayan Region. Nature Malaysiana, 16(4): 113-129.

Lowe-McConnell, K.H. 1975. Fish communities in tropical freshwater. Their distribution, ecology and evolution. Longman. London.

Makmur, S., Rahardjo, M.F., \& Sukimin, S. 2003. Biologi reproduksi ikan gabus (Channa striata Bloch) di daerah banjiran Sungai Musi Sumatera Selatan. Jurnal Iktiologi Indonesia, 3(2): 57-62.

Mishra, S.K. 1991. Reproductive biology of freshwater teleost, Channa gachua (Ham): Proceedings of The National Symposium on New Horizons in Freswater Aquaculture, p. 55-56.

Muflikhah, N. 2007. Domestikasi ikan gabus (Chana striatus). Bawal, 1(5):169-175.

Nikolsky, G.V. 1963. The ecology of fishes. Academic press. New York, 563 pp.

Nurdawati, S. 1995. Identifikasi jenis-jenis ikan di Sungai Batanghari, Jambi. Warta Penelitian dan Pengembangan Pertanian, $\mathrm{XVI}(4)$ : 4-6.

Nurdawati, S., Muflikhah, N., \& Sunarno, T.D. 2006. Sumber daya perikanan perairan Sungai Batanghari, Jambi. Bawal, 1(1): 1-9.
Prianto, E. \& Suryanti, N.K. 2009. Kebiasaan makan dan hubungan panjang bobot ikan gulamo keken (Johnius belangerii) di estuari Sungai Musi. Bawal, 2(6): 257-263.

Reidel, A., Boscolo, W.R., Feiden, A., \& Romagosa, E. 2010. The effects of diets with different levels of protein and energy on the process of final maturation of the gametes of Rhomdia quelen stocked in cages. Aquaculture, 298: 354-359.

Ruzafa, A.P., Wanguemert, M.G., Lenfant, P., Marcos, C., \& Charton, J.A.G. 2006. Effects of fishing protection on the genetic structure of fish populations. Biological Conservation, 129: 244-255.

Said, A. 2007. Beberapa jenis kelompok ikan Gabus (Marga Channa) di daerah aliran Sungai Musi, Sumatera Selatan. Bawal, 1 (4): 121-126.

Samuel, Adjie, S., \& Nasution, Z. 2002. Aspek lingkungan dan biologi ikan di Danau ArangArang Provinsi Jambi. J. Pen. Perik. Indonesia (edisi Sumber Daya dan Penangkapan), 1(8): 1-13.

Schreck, C.B. Contreras-Sanchez, W., \& Fitzpatrick, M.S. 2001. Effects of stress on fish reproduction, gamete quality, and progeny. Aquaculture, 197: 3-24.

Simanjuntak, C.P.H., Rahardjo, M.F., \& Sukimin, S. 2006. Iktiofauna rawa banjiran Sungai Kampar Kiri. Jurnal Iktiologi Indonesia, 6(2): 73-80.

Syandri, H. 1997. Perkembangan embrio dan larva ikan bilih (Mystacoleucus padangensis Blkr) di Danau Singkarak. Fisheries Journal Garing, 2(6): 28-38.

Syandri, H. 1998. Fekunditas, makanan, dan habitat pemijahan ikan bilih (Mystacoleucus padangensis Blkr.) di Danau Singkarak. Jurnal Iptekni, 2(6): 28-38.

Syandri, H. 2004. Penambahan vitamin E dalam pakan buatan untuk meningkatkan kualitas telur ikan garing (Tor douronensis Blkr). Jurnal Dinamika Pertanian, XIX(1): 141-151.

Utomo, A.D., Asyari, \& Nurdawati, S. 2001. Peranan suaka perikanan dalam meningkatkan produksi dan pelestarian sumber daya perikanan perairan umum. J. Pen. Perik. Indonesia, 1(7): 1-9.

Warsa, A., Nastiti, A.S., Krismono, \& Nurfiarini, A. 2008. Sumberdaya perikanan tangkap di Waduk Koto Panjang Riau. Bawal, 2(3): 93-97.

Wilson, D.S. \& Clarke, A.B. 1996. The shy and the bold. Natural History, 9(96): 26-28. 